\title{
Tilstræbt og realiseret tværfaglighed i universitetsundervisning
}

\author{
Katrine Lindvig, ph.d.-studerende, Institut for Naturfagenes Didaktik, Københavns \\ Universitet
}

Lars Ulriksen, professor, Institut for Naturfagenes Didaktik, Københavns Universitet

Videnskabelig artikel (anonym peer-review)

\begin{abstract}
Formailet med denne artikel er at give undervisere, som er involveret i tvæerfaglige uddannelser og undervisning, et grundlag for at kunne reflektere over og diskutere følgende: Hvad sker der med tværfagligheden i undervisningen, og hvordan hænger det sammen med de didaktiske valg i planlæegning og udforelse? I artiklen sammenholder og præsenterer forfatterne forst de mest udbredte betegnelser for tværfaglighed. Ved hiælp af en case bestående af et tværfagligt kursus, udbudt over flere gange og med forskelligt design, peger forfatterne herefter på nogle af de udfordringer, der er forbundet med at praktisere tværfaglig undervisning. Artiklen konkluderer, at centrale didaktiske overvejelser om stofudvælgelse, arbejdsformer, eksamensformer samt deltagerforudsætninger og forventninger har afgørende betydning for realiseringen af den tilstræbte tværfaglighed.
\end{abstract}

Tværfaglig undervisning på danske universiteter er ingen nyhed. Gennem mere end 40 år har tværfaglighed været et centralt kendetegn for universiteterne i Roskilde og Aalborg, og både før og efter har der været tværfaglige uddannelser og kurser på de øvrige universiteter. I disse år synes der dog at blive udbudt flere uddannelser og kurser på tværs af klassiske fag. Uddannelsesguiden (Undervisningsministeriet, 2015) viser et bredt udbud af tværfaglige uddannelser, især på kandidatniveau ( $f x$ Klimaforandringer og Afrikastudier), men også på bachelorniveau (fx SPRØK og Folkesundhedsvidenskab). Mange undervisere indgår derfor i en eller anden form for tværfaglig ramme og skal forholde sig til, hvad tværfaglighed er.

Julie Klein noterer i sin efterhånden kanoniske bog Interdisciplinarity (1990:55) at man sædvanligvis finder tværfaglighed defineret ud fra eksempler (hvordan kan tværfaglighed se ud?), ud fra begrundelser (hvorfor tværfaglighed?), ud fra principperne for samspillet mellem de involverede fag, eller ud fra et terminologisk hierarki - ofte i forhold til forskellige grader af integration.

Alle fire tilgange er legitime og kan hver for sig bidrage til at blive klogere på, hvad tværfaglighed kan være og hvilke vanskeligheder, der kan ligge i tværfagligheden. En del af litteraturen er imidlertid tilbøjelig til at anlægge et normativt perspektiv, hvor begrundelsen for tværfaglighed gives som idealer, og terminologier præsenteres i værdihierarkier. Skal man forstå tværfagligheden i praksis, er det dog nødvendigt at løsrive terminologien fra værdierne og bruge den til at indkredse de tværfaglige praksisser. Begrundelserne for tværfaglighed skal ligeledes frigøres fra idealerne og i stedet bruges til både at forstå, hvorfor en uddannelse eller et kursus ser ud, som de gør, og hvorfor de nogle gange udvikler sig anderledes end planlagt.

Formålet med denne artikel er at give undervisere, som er involveret i tværfaglige uddannelser og undervisning, et grundlag for at kunne reflektere over og diskutere følgende: Hvad sker der med tværfagligheden i undervisningen, og hvordan hænger det sammen med de didaktiske valg i planlægning og udførelse? Artiklen består af tre dele. 
- 1 . del præsenterer og sammenholder kort nogle af de betegnelser, som bruges til at beskrive og diskutere tværfaglighed.

- 2. del diskuterer en case, nemlig et kursus udbudt ad tre omgange inden for den samme uddannelse, men med tre forskellige design og hvor forskellige niveauer af tværfaglighed er i spil inden for samme kursus.

- 3. og sidste del samler op på, hvad vi kan lære af eksemplerne, ikke mindst med hensyn til sammenhængen mellem den tilstræbte og den realiserede tværfaglighed.

\section{Definitioner og kategoriseringer af tværfaglighed}

Der findes ingen entydig definition af forskellige typer af tværfaglighed, men der er alligevel nogle fælles træk i sprogbrugen. Det skyldes blandt andet, at mange beskrivelser griber tilbage til en terminologi præsenteret af astrofysikeren Eric Jantsch på en OECD-konference i 1972. Hans definitioner benyttes enten direkte eller som grundlag for videreudvikling i de mest citerede internationale tekster om tværfaglighed (bl.a. Klein, 1990, 1996; Lattuca, 2002; Moran, 2010; Newell, 1994; Weingart \& Stehr, 2000).

Jantsch (1972) opererede med fem niveauer, og Klein (1990) argumenterer for, at der på tværs af de omfattende forsøg på at fastlægge en terminologi tegner sig en enighed om tre hovedtyper. I tabellen har vi sammenstillet Jantschs og Kleins inddelinger sammen med et bud på en dansk oversættelse af navnene på de forskellige niveauer (Ulriksen, 2008). Endelig har vi i kolonnen yderst til højre peget på kvalitative forskelle mellem de tre trin (uddybes nedenfor).

\begin{tabular}{|l|l|l|l|l|}
\hline Niveau & Jantsch & Ulriksen & Klein & Kort sagt \\
\hline 1 & Multidisciplinarity & Mangefaglighed & \multirow{2}{*}{ Multidisciplinarity } & $1+1=2$ \\
\cline { 1 - 2 } & Pluridisciplinarity & Flerfaglighed & & \\
\hline 3 & Crossdisciplinarity & Støttefaglighed & Interdisciplinarity & $1+1=3$ \\
\hline 4 & Interdisciplinarity & Mellemfaglighed & Transdisciplinarity & $1+1=1$ \\
\hline 5 & Transdisciplinarity & Overskridende faglighed & &
\end{tabular}

De første to af J antschs fem niveauer, 'multidisciplinarity' ('mangefaglighed') og 'pluridisciplinarity' ('flerfaglighed') er kendetegnet ved en begrænset grad af kontakt mellem de involverede fag. 'Mangefagligheden' er en sidestillet vifte af forskellige fag, "without making explicit possible relationships between them" (Jantsch, 1972:15), mens 'flerfagligheden' rummer "cooperation without coordination" (ibid.). De forskellige fag sættes i forhold til hinanden, så de bidrager med forskellige vinkler i forhold til det faglige indhold. Med en 'flerfaglig' tilgang er emnet fælles, men de deltagende fag behandler hvert deres aspekt uden nødvendigvis at have særligt meget interaktion. Det kan være flere fag, som belyser det samme tema, fx arbejdsløshed, ud fra et juridisk, et psykologisk, et økonomisk og et litteræert perspektiv. Hvert perspektiv bidrager til en mere nuanceret forståelse af arbejdsløshed, men den juridiske tilgang bliver ikke udfordret af en psykologisk tilgang eller den litterære af en økonomisk.

På J antschs tredje niveau, 'crossdisciplinarity' ('støttefaglighed') skal et eller flere støttefag tilpasse sig det dominerende fags forståelser, tilgange og behov. J antschs første tre niveauer svarer til den første af Kleins typer, nemlig 'multidisciplinarity', hvor der er en modstilling af forskellige fag, som er "grundlæggende additiv, ikke integrerende" (Klein, 2010:56, vor oversættelse).

Det fjerde niveau hos Jantsch, 'interdisciplinarity' ('mellemfaglighed'), vil ofte tage udgangspunkt i en problemstilling på en måde, så der skabes noget fælles mellem fagene. Det er dog inden for den 'mellemfaglige' tilgang stadig muligt at skelne de forskellige faggrænser 
og forstå hvem, der bidrager med hvad. Derimod ligger der i 'transdisciplinarity' ('overskridende faglighed') en opløsning af oprindelige faggrænser til fordel for et fælles felt og en udvikling af nye metoder eller tilgange.

Klein skelner på samme måde mellem 'mellemfaglighed' og 'overskridende faglighed'. Hun forbinder 'interdisciplinarity' med en grad af integration mellem de fag, som indgår, og en integration, som ikke er overladt til de studerende, men hvor graden af integration kan variere. I mange tilfælde er denne form for tværfaglighed knyttet til løsning af problemer (teoretiske eller praktiske). Med 'transdisciplinarity' bevæger man sig fra en integration til en syntetisering om bestemte begreber eller forståelsesrammer ( $f x$ kybernetik eller systemteori (Klein, 1990:65)). Det er også ved 'transdisciplinarity', der er den største afstand mellem ideal og virkelighed, skriver hun. Kleins type 2 svarer altså til Jantschs niveau fire, mens niveau fem svarer til Kleins type 3.

\section{De kvalitative forskelle}

Kleins tre typer udtrykker nogle kvalitative spring, som vi har sammenfattet i kolonnen "Kort sagt". I den første lægges de deltagende fag blot ved siden af hinanden. 'Mangefagligheden' fører ikke nødvendigvis til en samlet forståelse (man kunne sige at $1+1=1+1$ ). I både 'flerfagligheden' og 'støttefagligheden' betyder inddragelsen af flere fag, at man kan se på et felt fra flere sider, men fordi de ikke bliver integreret, opstår der ikke noget ekstra. Derfor er $1+1=2$.

I 'mellemfagligheden' bliver summen af samarbejdet større end summen af de bidragende fag uden at grænserne mellem fagene forsvinder. Integrationen af fagene frem for den simple læggen-sammen betyder, at der opstår noget ekstra ud over enkeltfagene. I 'mellemfagligheden' bliver $1+1=3$. Der sker også noget nyt i den 'overskridende faglighed', men da der her tendentielt sker en opløsning af faggrænserne, bliver resultatet derfor noget nyt, selvstændigt og fritstående: $1+1=1$.

De kvalitative spring knytter sig altså til, hvorvidt der opstår noget ekstra men også til, hvorvidt de involverede fag bliver anfægtet af at indgå i det tværfaglige samarbejde. På Kleins trin 1 står fagene uanfægtede tilbage, mens de på trin 2 er nødt til at tilpasse sig de faglige sammenhænge, de indgår i, og på trin 3 mere eller mindre opløses. En del af forskellene i graden af tværfaglighed på trin 2 vedrører derfor, i hvilken udstrækning de involverede fag underordner sig det fælles anliggende, som tværfagligheden orienterer sig imod. Eksempelvis vil problembaseret projektarbejde ofte beskrive et problem ( $\mathrm{fx}$ en case) ud fra de faglige elementer, man ønsker, de studerende skal arbejde med. Her er faget det styrende. I det problemorienterede projektarbejde begynder man i problemet og inddrager derefter elementer fra fagene, som er relevante for at belyse problemet jf. Simonsen og Ulriksen (1998: 182ff.).

I den næste del vil vi illustrere forskellene og nuancerne mellem de forskellige definitioner og samtidig vise, hvor lidt der skal til, for at typen af tværfaglighed ændres i en undervisningssammenhæng. Det gør vi ved hjælp af en case fra vores igangværende forskning i tværfaglig undervisning og uddannelse på Københavns Universitet (KU). Her undersøger vi bl.a. hvordan tværfaglig forskning bliver til tværfaglig uddannelse, lige fra hvordan ideerne opstår, over hvordan forskerne planlægger uddannelsesaktiviteter, og hvordan disse aktiviteter bliver gennemført og modtaget af de studerende.

\section{Metode}

Casen består af et tværfagligt kursus som udbydes som tilvalgskursus på kandidatuddannelsen i Folkesundhedsvidenskab på KU. Kurset udspringer af et større tværfagligt forskningsprojekt omhandlende fedme. Planlægningen af kurset begyndte i efteråret 2013, og kurset blev afviklet første gang i efteråret 2014. Herefter blev det udbudt som sommerskole i sommeren 2015 og vil blive gentaget i sommeren 2016. 
Ved hjælp af etnografisk inspirerede metoder (Marcus, 1995; Willis, 2000) har vi fulgt planlægningen og udviklingen af kurset helt fra begyndelsen. Vi har deltaget i uddannelsesgruppens planlægningsmøder, været c.c. på samtlige mailkorrespondancer relateret til kurset, interviewet kursets undervisere før og efter deres undervisningsgange, gennemført tre fokusgruppeinterviews med i alt 12 studerende fra kurserne, observeret undervisning samt fulgt den mundtlige og skriftlige evaluering af de to gennemførte kursusforløb. Gennem hele forløbet har vi været i dialog med den kursusansvarlige og de øvrige deltagere i planlægningsgruppen om de didaktiske overvejelser relateret til kurset. Denne betydelige mængde empiri har vi kunnet producere, fordi vi fra starten har fået adgang til samtlige niveauer af planlægning, gennemførelse og evaluering - og fordi kursusforberedelsen efter vores vurdering har været ekstraordinært grundig.

Tværfaglighed vil komme forskelligt til udtryk i forskellige kurser og uddannelser. Med denne case ønsker vi imidlertid at vise, at der også inden for et enkelt kursus kan forekomme en række forskellige typer tværfaglighed. Ved at bruge et grundigt gennemarbejdet kursus som case (Flyvbjerg, 2011) får vi mulighed for at undersøge udfordringerne ved at realisere den tilstræbte tværfaglighed med fokus på de didaktiske udfordringer, frem for på bureaukrati, økonomi og logistik.

I de følgende afsnit vil vi kort gennemgå kursets udvikling, hvilke overvejelser, der var forbundet med typen af tværfaglighed samt de udfordringer, som opstod i gennemførelsen af kurset. I gennemgangen benytter vi tre metaforer til at beskrive de former, kurset antager. Disse metaforer illustrerer måden fagene bringes i forbindelse med hinanden på, frem for $i$ hvilken grad fagene integreres (som i tabellen). Metaforerne kan altså dække tilrettelæggelsesformer, som i princippet kan findes på flere af de niveauer, som er beskrevet i tabellen.

\section{Kandidatkursus 2014: Governing obesity}

Da kurset første gang blev gennemført i efteråret 2014, bar det titlen "Governing Obesity". Kurset blev udbudt på tværs af fakulteter og universiteter, og adgangskravet var en bachelorgrad inden for et relevant område. Kursets formål var ifølge kursusbeskrivelsen:

"[T]o introduce students to perspectives from several disciplines on obesity with the dual purpose of training interdisciplinary thinking and understanding, and an understanding of the complex causes and aspects of interventions towards obesity".

Dette formål afspejlede en af de bærende motivationer fra det bagvedliggende tværfaglige forskningsprojekt, nemlig at fedme er et så komplekst problem, at det umuligt kan forstås og løses med en enkeltfaglig tilgang.

Den første undervisningsgang omhandlede tværfaglighed og videnskabsteori og havde til formål at introducere en begrebsramme for de følgende ni undervisningsgange og samtidig klæde de studerende på til det tværfaglige arbejde. Hver undervisningsgang havde en titel ( $f x$ "Responsibility and stigma"), og på hver undervisningsgang à to timer underviste to forskere med forskellig baggrund. Underviserne kom fra en række fag på tværs af humaniora, samfunds- og naturvidenskab. Tanken var, at der på hver undervisningsgang blev knyttet an til de øvrige fagligheder og reflekteret over implikationer ved de forskellige tilgange. Efter hver anden undervisningsgang var der studenterpræsentationer på baggrund af opgaver knyttet til de foregående to undervisningsgange. Præsentationerne og opgaverne indgik som en del af de studerendes portfolioeksamen og skulle sammen med den afsluttende skriftlige opgave bestås, for at de studerende kunne opnå de 10 ECTS point. Som en måde at koble de forskellige undervisningsgange og fag, deltog kursuslederen i samtlige undervisningsgange. 
På baggrund af denne planlægning var tværfagligheden i kurset tænkt som 'mellemfaglig'. Der var en forventning om, at underviserne koblede deres fagligheder i undervisningsgangene, og de studerende forventedes at trække på deres forskellige fagligheder og inddrage forskellige faglige tilgange i deres afleveringer og præsentationer.

\section{Perler på snor}

Selvom der var lagt op til 'mellemfaglighed' på flere niveauer (emne, undervisere, metoder og studentersammensætning) blev "Governing Obesity" i realiteten snarere en blanding af et 'mangefagligt' og 'flerfagligt' kursus. Det kan der være flere forskellige grunde til:

I evalueringen gav de studerende udtryk for, at det især var en manglende kobling mellem de forskellige forelæsninger, der gjorde det svært at skabe en faglig syntese omkring det fælles emne. Stofmængden på kurset betød, at det ikke også kunne rumme sammenkædende diskussioner mellem de repræsenterede fagligheder, og selvom kursuslederen var til stede som bindeled mellem undervisningsgangene, var indholdet for forskelligt til at kunne bindes sammen.

I vores interview udtrykte underviserne forskellige holdninger til kursets formål: En af underviserne mente, at kurset skulle præsentere de studerende for en række topforskere inden for fedmeforskning, en anden pointerede nødvendigheden af tværfaglighed og forskellige faglige blikke på fedme, og en tredje understregede, at kursets formål var at give de studerende en række introduktioner til måder at arbejde med fedme på. De tre opfattelser udelukker ikke hinanden, og ingen af dem er sådan set forkerte i forhold til det endelige resultat. De kan dog alligevel have været medvirkende til, at de enkelte undervisningsgange mere kom til at fremstå som en række perler på en snor, end som et samlet hele med overlap mellem de forskellige faglige tilgange. Hvis de enkelte undervisere ikke er opmærksomme på at skabe overgange til de øvrige fag og ikke kender fagene, som de skal knytte an til, så bliver det svært for kursuslederen og for de studerende at kæde undervisningsgangene sammen.

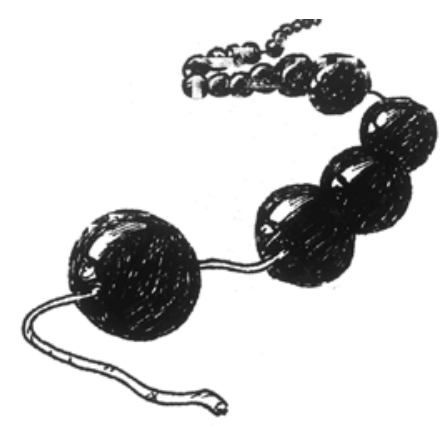

De studerende udtrykte, at der havde været en del forvirring om formålet med de forskellige opgaver og studenterpræsentationer. De var ikke klar over, om formålet var at lære en ny metode (fx posterpræsentation), eller om fokus var på indholdet. Det betød, at flere af de studerende holdt sig til det, de allerede kendte, og dermed ikke havde oplevet en integration af forskellige fag. Endelig blev studentersammensætningen heller ikke så mangfoldig som forventet (over $90 \%$ var fra Folkesundhedsvidenskab), hvilket også resulterede i en mindre grad af tværfaglighed de studerende imellem.

Ovenstående peger på, at selv små forstyrrelser kan have ret tydelige konsekvenser i et tværfagligt undervisningsmaskineri. Enkelte instrukser, som ikke videregives tydeligt nok, underviseres implicitte forståelser af kursusindhold og -sammenhæng samt en ændret studentersammensætning, kan ændre graden af tværfaglighed $\mathrm{n}$ til to niveauer ( $\mathrm{f}$. ovenstående skema). 


\section{Sommerskole 2015: Obesity in a crossdisciplinary perspective}

Hvor det første kursus blev udbudt som semesterkursus, blev dette udbudt som en to ugers intensiv sommerskole. Evalueringerne fra det første kursus resulterede først og fremmest i en ændring af kursusbeskrivelsen, således at ordet 'interdisciplinary' blev erstattet af 'crossdisciplinary' (ikke i J antschs betydning, men som en ikke nærmere præciseret ambition om at arbejde på tværs af fagene). Desuden reducerede man antallet af undervisere fra 17 til 12 og lod kursuslederen optræde flere gange igennem kurset med den hensigt at skabe sammenhæng. For at undgå stoftrængslen fra det første kursus, skar man ned på antallet af emner og fordoblede det antal timer, man brugte på hvert emne. Endelig ændrede man titlerne på undervisningsgangene, så flere af dem refererede direkte til de fag, de udsprang af ( $\mathrm{fx}$ "Law and discrimination", "Economy and obesity"). Der var stadig indlagt små opgaver, øvelser og gruppearbejde imellem de enkelte undervisningsgange, men da der ikke var samme mulighed for forberedelse som i semesterkurset, blev eksamensformen erstattet af en afsluttende essayopgave, som de studerende skulle aflevere en måned efter kursets afslutning.

Endelig skulle de studerende selv skabe integrationen mellem fagene i kurset. Det skulle ske i de studerendes individuelle og online kursusforberedelse, i gruppearbejde mellem studerende med forskellige fagligheder samt i eksamensopgaven, hvor de studerende blev bedt om at diskutere et emne/spørgsmål ud fra to forskellige faglige tilgange.

\section{Lynlåsen}

Kurset modtog yderst positive tilbagemeldinger fra de studerende. De syntes onlinedelen fungerede godt, og at det var nemt at orientere sig og få overblik over kursets forskellige dele. Kursuslederen havde gjort det klart, at de selv skulle koble de forskellige fag, og at det ikke var 'mellemfaglighed', men en mere sideordnet tværfaglighed, svarende til de tre niveauer, Klein kalder 'multidisciplinarity' (se tabellen), der var lagt op til. De studerende havde derfor ikke en forventning om en større integration af de enkelte fag. Dette forløb antog altså en anden form end det første kursus. Man kan sige, at der var tale om en lynlåsmodel, hvor de studerende skaber forbindelse mellem de forskellige fag, mens underviserne og undervisningen bliver på enkeltfagligt grundlag.

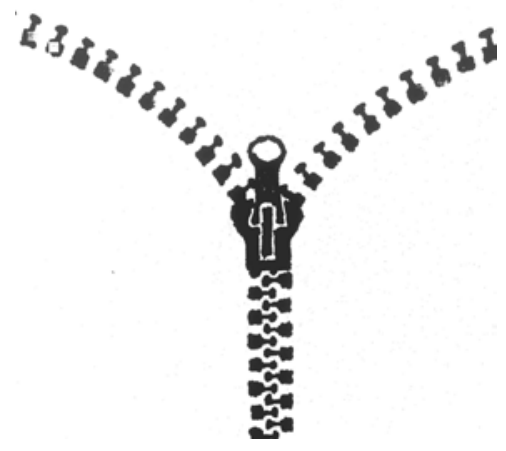

Den primære kritik af kurset vedrørte det faglige niveau. Fordi underviserne talte ud fra hver deres eksempler og indgange til fedmeproblematikken, var det meget forskelligt, hvordan de introducerede deres fag. Nogle undervisere indledte på et meget grundlæggende niveau, mens andre meget hurtigt bevægede sig op til et meget specialiseret og fagspecifikt niveau. Underviserne gav selv udtryk for, at de syntes det var svært at vurdere, hvor de skulle begynde, fordi gruppen af studerende var så blandet. Dette er en velkendt udfordring i tilrettelæggelsen af tværfaglig undervisning, idet der er så mange variabler i spil (Davis, 1995; Lattuca, Voigt \& Fath, 2004). De forskellige niveauer og tilgange i undervisningen betød også, at den afsluttende opgave ikke fungerede optimalt ift. at binde de forskellige 
dele sammen. Kravene blev undervejs ændret fra, at eksamensopgaven skulle rumme to perspektiver til kun ét perspektiv. At der i begge forløb har været udfordringer forbundet med eksamensdelen bekræfter det generelle billede af eksamination og evaluering af tværfaglig undervisning og uddannelse (Boix Mansilla \& Duraisingh, 2007; Haynes \& Leonard, 2010; Mansilla, 2005). Det er en udfordring at finde en metode, der kan vurdere den tværfaglige læring på tværs af faglige traditioner og kriterier og samtidig kan tale sammen med det øvrige og primært enkeltfaglige evalueringssystem.

\section{Sommerskole 2016: Obesity - a crossdiciplinary approach}

På baggrund af de to tidligere kursusforløb diskuterede planlægningsgruppen, hvordan man i sommerskolen 2016 kan styrke sammenhængen mellem de forskellige fag og samtidig sørge for, at undervisningsindholdet bevæger sig op over det introducerende niveau og bliver mere emnespecifikt. I de to forløb var undervisningsgangene centreret om hhv. tematikker og enkeltfaglige tilgange til fedme. Det satte meget fokus på de enkelte fag men mindre fokus på emnet og måden, de forskellige fag interagerer på. Det blev derfor foreslået at tilrettelægge en mere casebaseret undervisning med inspiration fra det bagvedliggende forskningsprojekt, så det ikke er fagene, der definerer undervisningsgangene, men en række spørgsmål, som samler fagene på tværs. Undervisningsgangene kan så struktureres omkring fem cases med to-tre undervisningsdage til hver, og med en gruppe af undervisere som vil kunne koordinere deres bidrag og tilbyde en mere fokuseret undervisning.

\section{Snekrystallen}

Hvis det lykkes at komme til at arbejde med nogle fælles cases og problemstillinger, så vil kurset kunne rumme tværfaglighed, som både er 'mangefaglig', 'flerfaglig' og måske også 'mellemfaglig'. Det er også muligt, at studerende med forskellig faglig baggrund kan skrive en opgave med fokus på en given case, hvor de benytter metoder fra et fag til at understøtte et andet og dermed skabe en form for 'støttefaglighed'.

Det vil have en betydning, at underviserne inden for de respektive cases mødes inden undervisningen og diskuterer sammenhænge, overgange og mulige overlap mellem deres forskellige fag. Endelig vil formuleringerne af de opgaver, som skal indgå i portfolioeksamen, være vigtige mht. at tydeliggøre, hvilken tværfaglighed man tilstræber hos de studerende. Med justeringer som disse vil der i givet fald være tale om tværfaglighed som antager form af en snekrystal, dvs. en række forskellige fag, som samles omkring et hele, og som griber ud og skaber tæette forbindelser imellem fagene.

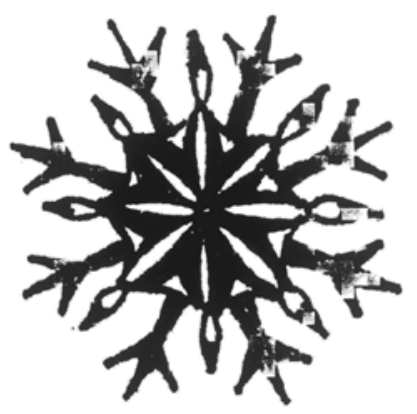

\section{Diskussion og konklusion}

Vores case peger dels på nogle af de former, tværfaglighed kan antage i undervisning og uddannelse, og dels på, at graden af tværfaglighed kan forandre sig, når blot nogle fă parametre ændres. De tre gennemløb viser, at der i den realiserede undervisning kan være flere forskellige typer tværfaglighed i spil (Klein, 1990:169) og være glidende overgange mellem typerne. De tre variationer af kurset viser samtidig betydningen af centrale didaktiske overvejelser om stofudvælgelse, arbejdsformer, eksamensformer samt om deltagerforudsætninger og forventninger. 
I første gennemløb hæmmede stoftrængsel tværfagligheden. Da stoftrængslen blev mindsket i andet forløb viste der sig problemer ved stofudvælgelsen, bl.a. fordi de studerendes forudsætninger var forskellige. Disse problemer blev muligvis forstærket af, at stofudvælgelsen i andet gennemløb var enkeltfaglig, fordi spredning i deltagerforudsætninger her får større betydning, end hvis indholdet udvælges i forhold til temaer. Erfaringerne fra tredje gennemløb i sommeren 2016 vil muligvis belyse dette.

Ydermere svækker tilrettelæggelse med udgangspunkt i et enkelt fag tværfagligheden ikke mindst hvis undervisningen varetages af mange specialister frem for færre undervisere, som kan forsøge at binde enkeltdelene sammen. Undervisning ud fra et fælles problem eller case (snekrystallen) vil kunne betyde, at det tværfaglige fremstår mere relevant, og at de studerende praktiserer tværfaglighed i kursets undervisningsaktiviteter.

Det peger hen på, hvilke forventninger der er til de studerendes rolle i skabelsen af tværfaglighed. I det andet gennemløb blev det eksplicit overladt til de studerende at skabe forbindelsen, og sammenknytningen skulle foregå uden for selve undervisningen. I det første gennemløb var forventningen, at tværfagligheden skulle skabes fælles i løbet af undervisningen, men uden at det lykkedes.

Endelig påvirkede eksamensformatet i begge realiserede tilfælde tværfagligheden. I første eksempel fordi læringsmålet ikke var klart for de studerende, og i det andet fordi kompleksiteten i kursustemaet fik kursuslederne til at mindske de tværfaglige ambitioner.

En bedre realisering af en tilstræbt tværfaglighed kan ske ved, at kursuslederen ekspliciterer sine forventninger til type og grad af integration mellem fagene, til måden man ønsker at dette skal lykkes på, samt til de forskellige aktørers rolle i denne integration. I den forbindelse er det vigtigere at gøre sig klart, hvilken type og grad der bedst tjener formålet med kurset, end at stræbe efter at opnå den storst mulige faglige integration.

Udviklingen af tværfaglig undervisning kan ikke alene foregå i beskrivelsen af læreplaner og kursusindhold. Det må også sætte sig spor i stofudvælgelsen, i den måde undervisningen tilrettelægges, og i den måde underviserne arbejder sammen på. Det kræver at planlæggere og undervisere afsætter ressourcer til en tæt koordinering og gensidig afklaring - både før og undervejs i undervisningen.

\footnotetext{
Katrine Lindvig er ph.d.-studerende ved Institut for Naturfagenes Didaktik på Københavns Universitet. Hun er uddannet cand.scient.soc. i Pæedagogik og Uddannelsesstudier samt Internationale Udviklingsstudier. I sit ph.d.-studie undersøger hun, hvordan forskellige typer af tværfaglig uddannelse og undervisning skabes i kølvandet på tværfaglig forskning. Forud for sit ph.d.-forløb har hun været tilknyttet forskningsprojekter omhandlende tværfaglig forskning og samarbejde, faglig identitet på nye universitetsuddannelser samt hybride kvalifikationer i erhvervsuddannelserne.
}

Lars Ulriksen er professor i Naturfagenes Uddannelsessociologi ved Institut for Naturfagenes Didaktik på Københavns Universitet. Hans primære forskningsinteresse er mødet mellem deltagerne og uddannelser, herunder uddannelsernes opbygning, de undervisningsformer som bruges, og hvad det forudsætter hos deltagerne - ikke mindst hos de studerende. Han har tidligere beskæftiget sig med projektarbejde og tværfaglighed og de udfordringer, uddannelsernes enkeltfaglige traditioner stiller tværfaglighed overfor. 


\section{Litteratur}

Boix Mansilla, V. \& Duraisingh, E. D. (2007). Targeted assessment of students' interdisciplinary work: An empirically grounded framework proposed. The Journal of Higher Education, 78(2), 215-237. doi: 10.1353/jhe.2007.0008

Davis, J. R. (1995). Interdisciplinary courses and team teaching: new arrangements for learning. Phoenix, Ariz: . American Council on Education and the Oryx Press.

Flyvbjerg, B. (2011). Case study. I: N. K. Denzin \& Y. S. Lincoln (red.), The Sage Handbook of Qualitative Research (4th edition) (s. 301-316). Los Angeles/London/New Delhi/Singapore/Washington DC: SAGE Publications.

Haynes, C. \& Leonard, J. B. (2010). From surprise parties to mapmaking: Undergraduate journeys toward interdisciplinary understanding. The Journal of Higher Education, 81(5), 645-666.

Jantsch, E. (1972). Inter- and transdisciplinary university: A systems approach to education and innovation. Higher Education, 1(1), 7-37. doi: 10.1007/BF01956879

Klein, J. T. (1990). Interdisciplinarity: history, theory, and practice. Detroit: Wayne State University Press.

Klein, J. T. (1996). Crossing Boundaries: Knowledge, Disciplinarities, and Interdisciplinarities. Charlottesville, Va: University Press of Virginia.

Klein, J. T. (2010). A taxonomy of interdisciplinarity. I: R. Frodeman, J. T. Klein \& C. Mitcham (red.), The Oxford Handbook of Interdisciplinarity (s. 15-30). Oxford: Oxford University Press.

Lattuca, L. R. (2002). Learning interdisciplinarity: Sociocultural perspectives on academic work. The Journal of Higher Education, 73(6), 711-739. doi: 10.1353/jhe.2002.0054

Lattuca, L. R., Voigt, L. J. \& Fath, K. Q. (2004). Does interdisciplinarity promote learning? Theoretical support and researchable questions. Review of Higher Education, 28(1), 23-48.

Mansilla, V. B. (2005). Assessing student work at disciplinary crossroads. Change: The Magazine of Higher Learning, 3ᄌ1), 14-21. doi: 10.3200/CHNG.37.1.14-21

Marcus, G. E. (1995). Ethnography in/of the world system: The emergence of multi-sited ethnography. Annual Review of Anthropology, 24, 95-117.

Moran, J. (2010). Interdisciplinarity (2. ed.). London: Routledge.

Newell, W. H. (1994). Designing interdisciplinary courses. New Directions for Teaching and Learning, 1994, 35-51. doi: 10.1002/tl.37219945804

Simonsen, B. \& Ulriksen, L. (1998). Universitetsstudier i krise. Fag, projekter og modeme studenter (Vol. 94/98). Frederiksberg: Roskilde Universitetsforlag.

Ulriksen, L. (2008). Det sociologiske perspektiv. I F. B. Olsen \& F. Held (red.), Introduktion til paedagogik. Opdragelse - Dannelse - Socialisering (2. udg.), s. 49199). Frederiksberg: Frydenlund.

Undervisningsministeriet. (2015). Uddannelsesguiden. Fundet 22. oktober, 2015, på www.ug.dk.

Weingart, P. \& Stehr, N. (2000). Practising Interdisciplinarity. Toronto: University of Toronto Press.

Willis, P. (2000). The Ethnographic Imagination. Cambridge: Polity. 